\title{
Determination of neophytadiene in the subcutaneous fat of Iberian pigs from different feeding systems
}

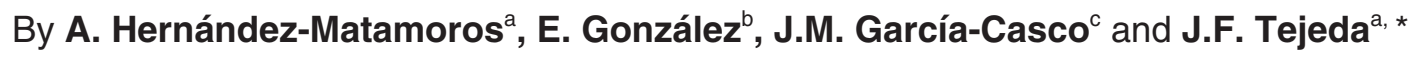 \\ ${ }^{a}$ Food Technology and Biochemistry, Escuela de Ingenierías Agrarias, Universidad de Extremadura, \\ Ctra. de Cáceres s/n, 06071 Badajoz, Spain \\ ${ }^{\mathrm{b}}$ Animal Production, Escuela de Ingenierías Agrarias, Universidad de Extremadura, Ctra. de Cáceres s/n, \\ 06071 Badajoz, Spain \\ ${ }^{\mathrm{C}}$ Centro de I+D en Cerdo Ibérico - INIA, Ctra. EX-101 km 4,7, 06300 Zafra, Spain \\ * Corresponding author: jftejeda@ unex.es
}

\begin{abstract}
RESUMEN
Determinación de neofitadieno en grasa subcutánea de cerdo lbérico con diferentes sistemas de alimentación

El objetivo del trabajo se centró en determinar el contenido de un hidrocarburo ramificado (neofitadieno) en la grasa subcutánea del cerdo ibérico, y su relación con el tipo de alimentación recibida durante la etapa de cebo previa al sacrificio (en la fase final de cebo). Para ello, se estudiaron treinta y seis lotes de cerdos lbéricos, pertenecientes a las cuatro categorías de calidad en base a la alimentación de los animales establecidas en la Norma de Calidad (Bellota, Recebo, Campo y Cebo). Estas categorías se diferencian en el grado de aprovechamiento de los recursos naturales de la dehesa (bellotas y hierba) y en el nivel de sustitución de los mismos por piensos concentrados. Para el aislamiento e identificación de los hidrocarburos se utilizaron técnicas de SPE combinadas con GC-MS. Los lotes de Recebo y Bellota presentaron los mayores niveles de neofitadieno, seguidos por los lotes de Campo, y por último los lotes de Cebo. Se observó una gran variabilidad en los niveles de neofitadieno entre los lotes pertenecientes a una misma categoría de alimentación, sobre todo en los lotes de Bellota, Recebo y Campo, por lo que es difícil una correcta clasificación de los animales en las tres categorías en base al contenido en neofitadieno. Sin embargo, la clasificación dentro de la categoría de cebo se hace de forma correcta cuando los cerdos son producidos en condiciones intensivas.
\end{abstract}

PALABRAS CLAVE: Alimentación - Cerdo Ibérico - Clasificación - Grasa subcutánea - Neofitadieno.

\section{SUMMARY}

Determination of neophytadiene in the subcutaneous fat of Iberian pigs from different feeding systems

This study was carried out in order to determine the relationship between the content of a branched hydrocarbon (neophytadiene) in the subcutaneous fat and the feeding system of Iberian pigs during the fattening period previous to slaughter. Thirty-six batches of Iberian pigs, belonging to the four categories of feeding systems described in the Spanish legislation (Bellota, Recebo, Campo and Cebo) were studied. These categories differ in their degree of utilization of the natural resources (acorn and pasture) of the extensive rearing system or in their level of replacement by concentrated feed.
SPE combined with GC-MS techniques were carried out to isolate and to identify hydrocarbons. Recebo and Bellota batches showed the highest levels of neophytadiene content, followed by Campo batches, and finally, batches of the Cebo category. The results showed a great variability between batches from the same feeding category, mainly from Bellota, Recebo and Campo categories, which makes the classification of the animals in these three categories difficult. However, the animals from the Cebo category were correctly classified when reared in intensive conditions.

KEY-WORDS: Classification - Feeding - Iberian pig Neophytadiene - Subcutaneous fat.

\section{INTRODUCTION}

The unsaponifiable fraction of oils and fats contains small quantities of saturated and unsaturated hydrocarbons. These compounds normally occur in animal tissues and are derived mainly from plant origin, being important components of vegetable wax (Post-Beittenmiller, 1996). For that reason, several authors have related the presence of specific hydrocarbons in animal tissues to the feed, mostly of plant origin, consumed by the animals (Tulliez and Bories, 1978; Tejeda et al., 2001b; Gamero et al., 2006). Hydrocarbons are inert in the digestive tract and are little modified during digestion and metabolism (Mayes et al., 1988; Rembold et al., 1989); however, they are absorbed at low doses by the mammalian small intestine (Tulliez and Bories, 1975) and the absortion decreases with the increase of chain length of the hydrocarbons (Mayes and Lamb, 1984). Several authors have described saturated, unsaturated and branched hydrocarbons in ruminant animal tissues (Bandurski and Nagi, 1975; Lintas et al., 1979). In monogastric animals, like the Iberian pig, $n$-alkanes (parafinic hydrocarbons) and $n$-alkenes, from $n-C_{12}$ to $n-C_{33}$ have been identified in subcutaneous (Tejeda et al., 1999; Gamero et al., 2006) and intramuscular (Tejeda et al., 2001a) fat, with the odd numbered carbon chains being the most abundant. Petrón et al. (2004) have also identified $\mathrm{n}$-alkanes and n-alkenes in intramuscular fat from 
dry-cured hams. Other studies have focused on the analysis of the branched hydrocarbon fraction in Iberian pig adipose tissues. In this sense, Tejeda et al. (2001b) identified neophytadiene, a diterpenoid hydrocarbon that belongs to the group of compounds known as phytanes, in intramuscular lipids from B. femoris muscle and Petrón et al. (2005) in intramuscular lipids from dry-cured ham.

The analysis of the hydrocarbons in the unsaponifiable fraction is difficult as they are present at low concentrations (Tejeda et al., 1999), usually below the limit of detection of the analytical methods (Gamero et al., 2006). Chromatographic techniques are adequate to separate and quantify these compounds. Some authors (Bernardini et al., 1982; Tejeda et al., 1999) use thin layer chromatography (TLC) to isolate n-alkanes and n-alkenes. The use of solid phase extraction (SPE) technique, instead of TLC methods, as concentration step allows a substantial reduction in analysis time. Then, gas chromatography coupled to mass spectrometry (GC-MS) can be applied to identify and quantify hydrocarbons (Tejeda et al., 2001a; Petrón et al., 2004). More recently, an off-line combination of HPLC and gas chromatography multi-stage mass spectrometry (GC-MS ${ }^{3}$ ) has been used to detect and quantify the hydrocarbon fraction (NarváezRivas et al., 2008). Moreover, purge and trap GCMS combined with chemometrical tools have been applied to the authentication of the fattening systems of lberian pigs (Narváez-Rivas et al., 2010 and 2011).

The analysis of the hydrocarbon fraction is of great interest since it could contribute to differentiating among the types of diet given to the Iberian pigs previous to slaughter. Spanish legislation classifies Iberian pig products into different categories depending on the feeding regime and production system involved (BOE, 2007): Bellota (i.e. free-range animals fed on acorn and pasture), Recebo (i.e. animals fed on acorns and pasture supplemented with concentrate feeds in an outdoor system), Campo (i.e. animals fed on concentrate feeds in an outdoor system) and Cebo (i.e. animals fed on concentrate feeds in an intensive system). The Bellota category is the highest priced in the market, followed by Recebo, Campo and then by Cebo. Therefore, different methods, based on chemical analysis of different hydrocarbon fraction compounds, as n-alkanes (Tejeda et al., 2001a; Petrón et al., 2004), n-alkenes (Viera-Alcaide et al., 2009), neophytadiene (Tejeda et al., 2001b; Petrón et al., 2005), ent-kaurene (Narváez-Rivas et al., 2008) or volatile compounds (Narváez-Rivas et al., 2010 and 2011) have been carried out to differentiate among the products obtained from these fattening systems.

The aim of the present study was to determine the content of a branched hydrocarbon of the unsaponifiable fraction (neophytadiene) from subcutaneous fat, and its relationship with the management feeding system of lberian pigs according with the four categories (Bellota, Recebo, Campo and Cebo) as defined by the Spanish legislation.

\section{MATERIALS AND METHODS}

\subsection{Materials}

\subsubsection{Animal and diets}

In this study a total of 725 lberian pigs separated into 36 batches according to the feeding system during the final fattening period of pigs (Bellota, Recebo, Campo and Cebo) from November to March in three consecutive years (2008/2009, 2009/2010 and 2010/2011) was analyzed (see Table 1). A detailed description of these batches of animals can be found in a parallel paper by García-Casco et al., 2013. After slaughtering by electric stunning and exsanguinations at different local slaughterhouses, backfat samples were taken $10 \mathrm{~cm}$ above the tail, were vacuum packaged and maintained at $-20^{\circ} \mathrm{C}$ until analysis.

\subsubsection{Reagents and standards}

Hexane Multisolvent ${ }^{\mathrm{TM}}$ HPLC ACS grade supplied by Scharlau (Barcelona, Spain) was used for hydrocarbon extraction, column fractionation and as HPLC solvent. Potassium hydroxide $85 \%$ pellets PA-ACS grade were supplied by Panreac (Barcelona, Spain). Ethanol absolute Multisolvent ${ }^{\mathrm{TM}}$ ACS grade was supplied by Scharlau (Barcelona, Spain). Sodium sulphate anhydrous extra pure was supplied by Scharlau (Barcelona, Spain). Aminopropyl $500 \mathrm{mg}$ minicolums Strata $\mathrm{NH}_{2}(55 \mu \mathrm{m}, 70$ A) from Phenomenex (Torrance, USA) were used for column chromatography. Nonadecane (n-C19; Sigma Chemical Co., St. Louis, MO, USA) was used as an internal standard.

\subsection{Methods}

The hydrocarbon fraction of subcutaneous fat was determined by a modification of the method of Tejeda et al. (2001b) and applied to intramuscular fat. This modification, described by Fernández (2007), involves the lipid extraction method, saponification time, SPE purification and gas chromatography conditions.

\subsubsection{Lipid extraction}

Samples of subcutaneous fat were trimmed and minced and lipids were extracted by heating in a microwave oven for 2 minutes at $550 \mathrm{~W}$ according to the method described by De Pedro et al. (1997).

\subsubsection{Saponification}

Two grams of extracted lipids were saponified by refluxing for $15 \mathrm{~min}$ at $100{ }^{\circ} \mathrm{C}$ with $70 \mathrm{~mL}$ of $15 \% \mathrm{KOH}$ in ethanol (w/v). The warm solution was transferred to a separating funnel, $70 \mathrm{~mL}$ of distilled water were added and the unsaponifiable fraction was extracted with $70 \mathrm{~mL}$ of hexane. The organic 
Table 1

Neophytadiene contents (relative area units expressed as peak area $\times 100 /$ internal standard peak area) from subcutaneous fat from the different batches of Iberian pigs fed on Bellota, Recebo, Campo and Cebo systems

\begin{tabular}{|c|c|c|c|c|c|}
\hline \multirow{2}{*}{ Batch } & \multirow{2}{*}{ Year } & \multirow{2}{*}{ no samples } & \multicolumn{3}{|c|}{ Neophytadiene } \\
\hline & & & Mean & SD $^{a}$ & $\% \mathbf{C V}^{\mathrm{b}}$ \\
\hline \multicolumn{6}{|l|}{ Bellota } \\
\hline B08-1 & 2008 & 29 & 9.3 & 4.4 & 46.8 \\
\hline B08-2 & 2008 & 32 & 4.3 & 2.9 & 67.2 \\
\hline B09-1 & 2009 & 25 & 9.1 & 5.1 & 55.4 \\
\hline B09-2 & 2009 & 25 & 15.4 & 5.9 & 38.0 \\
\hline B10-1 & 2010 & 13 & 5.6 & 1.6 & 29.2 \\
\hline B10-2 & 2010 & 16 & 2.4 & 1.1 & 45.9 \\
\hline B10-3 & 2010 & 8 & 4.8 & 0.9 & 18.2 \\
\hline B10-4 & 2010 & 8 & 7.2 & 2.5 & 35.5 \\
\hline B10-5 & 2010 & 15 & 5.7 & 3.0 & 52.8 \\
\hline B10-6 & 2010 & 15 & 4.7 & 2.5 & 51.9 \\
\hline B10-7 & 2010 & 15 & 5.3 & 2.3 & 44.5 \\
\hline B10-8 & 2010 & 14 & 3.0 & 1.5 & 49.0 \\
\hline B10-9 & 2010 & 15 & 3.7 & 1.3 & 34.8 \\
\hline B10-10 & 2010 & 14 & 4.6 & 1.1 & 24.1 \\
\hline \multicolumn{6}{|l|}{ Recebo } \\
\hline R08-1 & 2008 & 28 & 3.4 & 1.2 & 36.2 \\
\hline R08-2 & 2008 & 12 & 4.2 & 1.2 & 29.1 \\
\hline R09-1 & 2009 & 25 & 17.4 & 7.4 & 42.2 \\
\hline R09-2 & 2009 & 9 & 12.0 & 3.9 & 32.3 \\
\hline R10-1 & 2010 & 8 & 3.9 & 1.6 & 39.8 \\
\hline R10-3 & 2010 & 20 & 4.1 & 1.6 & 38.6 \\
\hline R10-4 & 2010 & 19 & 5.3 & 2.6 & 49.5 \\
\hline R10-5 & 2010 & 15 & 11.9 & 4.3 & 36.2 \\
\hline \multicolumn{6}{|l|}{ Campo } \\
\hline CA08-1 & 2008 & 13 & 0.8 & 0.4 & 46.8 \\
\hline CA08-2 & 2008 & 23 & 3.7 & 1.5 & 41.3 \\
\hline CA08-3 & 2008 & 39 & 5.2 & 2.2 & 41.9 \\
\hline CA09-1 & 2009 & 25 & 1.4 & 0.7 & 49.1 \\
\hline CA09-2 & 2009 & 25 & 4.4 & 2.3 & 53.1 \\
\hline CA09-3 & 2009 & 25 & 9.4 & 4.1 & 43.9 \\
\hline CA10-1 & 2010 & 22 & 1.3 & 0.6 & 41.5 \\
\hline CA10-2 & 2010 & 22 & 1.1 & 0.4 & 40.5 \\
\hline \multicolumn{6}{|l|}{ Cebo } \\
\hline CE08-1 & 2008 & 32 & 0.0 & 0.0 & 0.0 \\
\hline CE09-1 & 2009 & 25 & 0.0 & 0.0 & 0.0 \\
\hline CE10-1-2 & 2010 & 18 & 0.8 & 0.2 & 33.4 \\
\hline CE10-3 & 2010 & 15 & 0.0 & 0.0 & 0.0 \\
\hline CE10-4 & 2010 & 23 & 0.9 & 0.3 & 42.2 \\
\hline CE10-5 & 2010 & 22 & 0.0 & 0.0 & 0.0 \\
\hline
\end{tabular}

${ }^{a}$ Standard deviation.

${ }^{\mathrm{b}}$ Coefficient of variation. 
layer was washed three times with $50 \mathrm{~mL}$ of distilled water, then dried over anhydrous sodium sulphate and subsequently concentrated to $2 \mathrm{~mL}$.

\subsubsection{Solid phase extraction (SPE)}

The concentrate was transferred onto an aminopropyl $500 \mathrm{mg}$ minicolum using $30 \mathrm{~mL}$ of hexane for hydrocarbon elution. After evaporating to dryness under vacuum, the residue was dissolved in $1 \mathrm{~mL}$ of hexane, and $50 \mu \mathrm{L}$ were taken for the gas chromatographic analysis.

\subsubsection{Identification and quantitative determination of hydrocarbons}

Hydrocarbons were identified and quantified on an Agilent 6890 chromatograph, using a Hewlett Packard fused silica capillary column (12 m $\times$ $0.2 \mathrm{~mm}$ i.d.) equipped with an Agilent 5973 mass selective detector. The oven program was from 100 to $196^{\circ} \mathrm{C}$ at $6^{\circ} \mathrm{C} \mathrm{min}^{-1}$, and from $196^{\circ} \mathrm{C}$ to $280^{\circ} \mathrm{C}$ at $30^{\circ} \mathrm{C} \mathrm{min}{ }^{-1}$, finally the oven was held at $280^{\circ} \mathrm{C}$ for $15 \mathrm{~min}$. Total analysis time was $33.8 \mathrm{~min}$. Injector temperature was $260^{\circ} \mathrm{C}$, and the GC-MS transfer line temperature was held at $280^{\circ} \mathrm{C}$. The split ratio was 1:25, inlet pressure $14 \mathrm{psi}$, and the injected volume was $2 \mu \mathrm{L}$. The mass spectrometer operated in the electron impact mode with an electron energy of $70 \mathrm{eV}$, a multiplier voltage of
$1756 \mathrm{~V}$ and collected data at $1 \mathrm{scan} / \mathrm{s}$ over a m/z range from 40 to 300 . Spectra were compared with those of the standards and spectra from the NIST (National Institute of Standards and Technology) library. Quantitative determination was performed by adding an appropriate amount of the internal standard ( $n$-nonadecane, $n-C_{19}$ ) to the final extract. The relative response factor was close to the unit. Results were expressed as peak area $\times 100 /$ internal standard peak area (relative area units).

\subsubsection{Statistical analysis}

The results were subjected to analysis by a Kruscal-Wallis test for $k$ samples, which is the nonparametric equivalence of one way ANOVA. An individual animal was the experimental unit for analysis of all data. The model used involved the category of feeding system. Mann-Whitney post hoc tests were used for comparison among treatments. This statistical procedure was carried out using software Statistical Package for the Social Sciences (SPSS) package (v.19).

\section{RESULTS AND DISCUSSION}

\subsection{Identification of hydrocarbons}

Figure 1 shows the GC-MS chromatogram of the hydrocarbon fraction isolated from subcutaneous

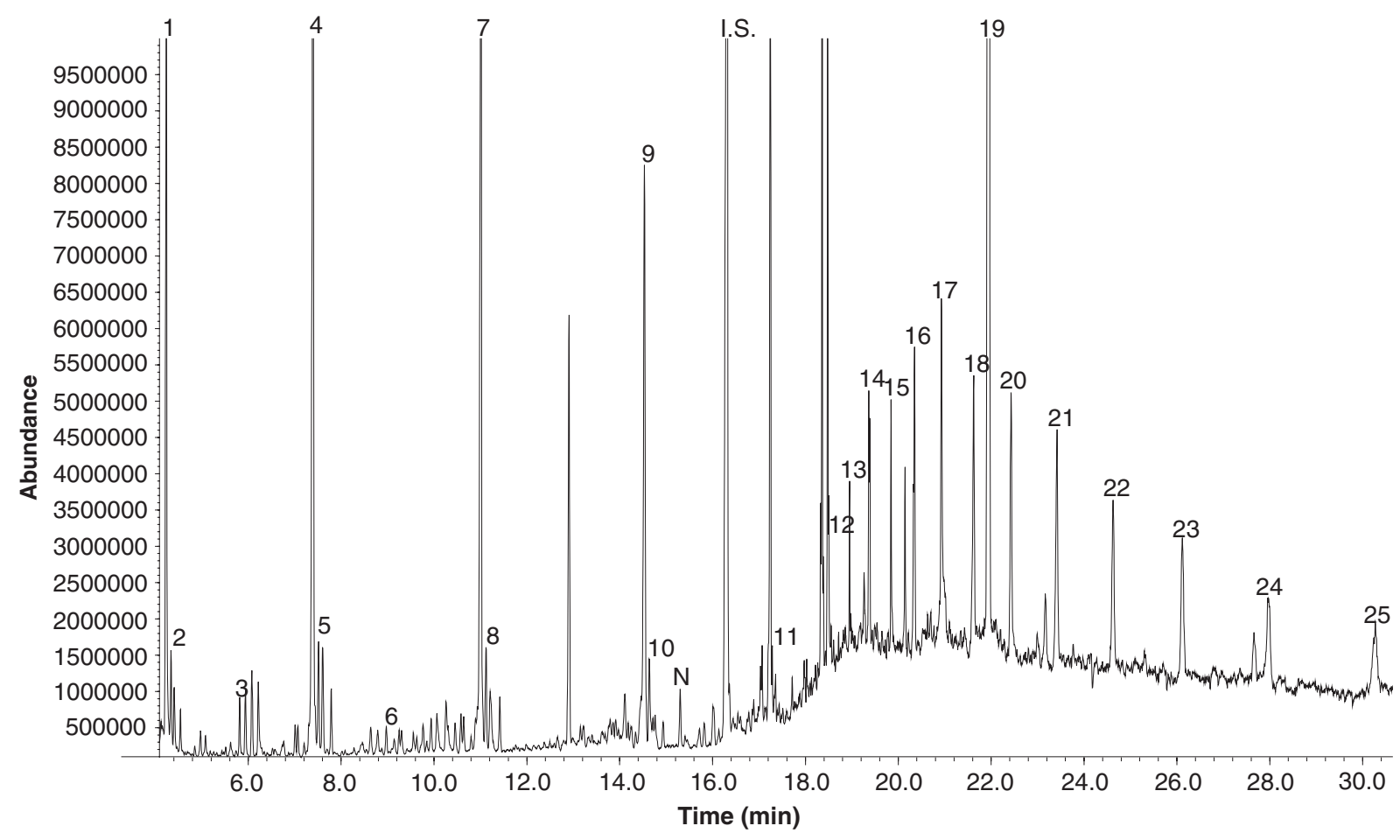

Figure 1

GC-MS chromatograms of hydrocarbons identified in subcutaneous fat. 1: dodecene $\left(n-C_{12: 1}\right)$; 2: dodecane $\left(n-C_{12}\right) ; 3$ : tridecane $\left(n-C_{13}\right)$; 4: tetradecene $\left(n-C_{14: 1}\right) ; 5$ : tetradecane $\left(n-C_{14}\right) ; 6$ : pentadecane $\left(n-C_{15}\right) ; 7$ : hexadecene $\left(n-C_{16: 1}\right) ; 8$ : hexadecane $\left(n-C_{16}\right)$;

9: octadecene $\left(n-C_{18: 1}\right) ; 10$ : octadecane $\left(n-C_{18}\right) ; 11$ : eicosane $\left(n-C_{20}\right)$; 12: heneicosane $\left(n-C_{21}\right)$; 13: docosane $\left(n-C_{22}\right)$;

14: tricosane $\left(n-C_{23}\right)$; 15: tetracosane $\left(n-C_{24}\right)$; 16: pentacosane $\left(n-C_{25}\right)$; 17: hexacosane $\left(n-C_{26}\right)$; 18: heptacosane $\left(n-C_{27}\right)$;

19: squalene; 20:octacosane $\left(n-C_{28}\right) ; 21$ : nonacosane $\left(n-C_{29}\right) ; 22$ : triacontane $\left(n-C_{30}\right) ; 23:$ hentriacontane $\left(n-C_{31}\right) ; 24$ : dotriacontane $\left(\mathrm{n}-\mathrm{C}_{32}\right) ; 25$ : tritriacontane $\left(\mathrm{n}-\mathrm{C}_{33}\right)$; $\mathrm{N}$ : neophytadiene; I.S.: internal standard (nonadecane). 
fat. The peaks of chromatograms were identified comparing the GC-MS spectra with those from the National Institute of Standard and Technology (NIST) libraries. Both n-alkanes and n-alkenes were identified, being $n$-alkenes of even chain between $n-C_{12: 1}$ and $n-C_{20: 1}$ the most abundant, followed by the correspondent n-alkanes, in accordance with the results obtained by Gamero et al. (2006) in subcutaneous fat, and by Petrón et al. (2004) in intramuscular lipids from Iberian dry-cured ham. Hydrocarbons are preferentially concentrated in subcutaneous adipose tissues, followed by perirrenal and intramuscular fat (Lintas et al., 1979). Even-numbered (enca) and odd-numbered carbon atoms (onca) $n$-alkane in the $n-C_{12}$ to $n-C_{33}$ range were present in the unsaponifiable fraction of subcutaneous fat. However, odd chain n-alkenes were not identified in chromatograms, in agreement with previous bibliography on the Iberian pig (Petrón et al., 2004 and 2005; Gamero et al., 2006). Some other peaks were observed in the chromatograms and were identified as branched hydrocarbons, as squalene and neophytadiene, among others. The mass spectrum obtained when analyzing the peak at retention time 15.31 (N) was (except for the molecular ion, only fragments with relative abundances greater than $15 \%$ are given): $\mathrm{m} / \mathrm{z} 53$ (15\%), 55 (70\%), 56 (20\%), 57 (74\%), 67 (57\%), 68 (100\%), 69 (66\%), 70 (16\%), 71 (38\%), 79 (19\%), $81(58 \%), 82$ (72\%), 83 (48\%), 95 (85\%), 96 (27\%), 97 (34\%), 109 (27\%), 111 (17\%), 123 (52\%), 124 $(20 \%), 278(3 \% M+)$. The rest of the branched hydrocarbons corresponded to those having a linear or cyclical chain with one or more branched methyl groups, which could explain, together with their low concentrations, that several of these compounds remain unidentified. In the literature, several authors have reported the same problems in identifying some of the branched hydrocarbons in many animal tissues (Bastic et al., 1989; Berdagué and García, 1990; García et al., 1991; Petrón et al., 2005). The existence of branched hydrocarbons in bovine (Lintas et al., 1979) and pig (Bastic et al., 1989; Bernardini et al., 1982) tissues have been reported. Berdagué and García (1990) analyzed volatiles in dry-cured hams and found a number of branched hydrocarbons, while branched hydrocarbons of low molecular weight were isolated from Iberian dry-cured ham by García et al. (1991) and Ruiz et al. (1999). Tejeda et al. (1999) also found these compounds in adipose tissue from Iberian dry-cured ham. Squalene is the major branched hydrocarbon identified in chromatograms, in agreement with previous studies on the Iberian pig (Tejeda et al., 2001b; Petrón et al., 2005; Gamero et al., 2006). However, squalene presence in adipose tissues is mainly an intermediary product in cholesterol synthesis (Stryer, 1990), which explains the absence of differences in concentration of this compound in adipose tissues of Iberian pigs due to feeding system (Tejeda et al., 2001b; Petrón et al., 2005). Neophytadiene (3-methylene-7,11,15-trimethylhexadecen-1-ene) is a branched hydrocarbon belonging to the group of compounds known as phytanes, and is abundant in plant cuticular waxes (Lintas et al., 1979). Other authors, using HPLC technique for the purification of the hydrocarbon fraction, followed by GC-MS ${ }^{2}$, suggest that this compound is an isomeric form of neophytadiene (Gamero et al., 2006). Previous papers reported the presence of higher levels of neophytadiene in pasture, while this compound was not present in the acorns or concentrate consumed by Iberian pigs during the fattening period. Therefore, neophytadiene can be used as a key parameter to differentiate among types of diet given to the animals previous to slaughter (Tejeda et al., 2001b). These authors found a clear effect of feeding regime of the Iberian pig on the concentration of neophytadiene in the intramuscular lipids, with higher contents in intramuscular lipid from pigs raised extensively with acorn and pasture for a longer period of time. In contrast, neophytadiene was not identified in Iberian pigs fed on an intensive system with a concentrated diet (Tejeda et al., 2001b, Petrón et al., 2005).

\subsection{Neophytadiene subcutaneous fat contents}

Table 1 shows the neophytadiene contents in the subcutaneous fat from the different batches of Iberian pigs which were studied based on feeding systems (Bellota, Recebo, Campo and Cebo). Fourteen batches of Iberian pigs raised on the Bellota system were studied, which showed levels of neophytadiene ranging from 2.4 to 15.4 and a mean value of $6.8 \pm 3.1$ relative area units (expressed as peak area $\times 100 /$ internal standard peak area). In both Recebo and Campo systems eight batches of animals were studied with contents of neophytadiene from 3.4 to 17.4 , and 0.8 to 9.4 , being $7.6 \pm 6.4$ and $3.8 \pm 2.4$ the mean of the batches, respectively. Finally, six batches were analyzed in the Cebo category, where neophytadiene varied between 0.0 and 0.9 , with $0.3 \pm 0.2$ relative area units as the mean value of the group. The results showed a great variability between batches for a same category of feeding system, mainly in the Bellota, Recebo and Campo systems, which are feeding systems based on extensive or semi-extensive rearing conditions, with free access of the pigs to pasture. Regarding the Cebo system, neophytadiene was not identified in GC-MS chromatograms in four batches of animals studied, which could be explained by the fact that pigs are maintained in intensive conditions throughout the production period. However, two lots of animals presented a low neophytadiene content, which can be explained because the pigs were raised with pasture in semi-extensive conditions before the end of fattening in intensive conditions. Neophytadiene is the most abundant hydrocarbon in pasture, but is not present in acorn and concentrate feeds (Tejeda et al., 2001b), thus the presence of neophytadiene in subcutaneous fat is associated with the consumption of pasture. In this sense, Tejeda et 
Table 2

Mean and standard deviation of neophytadiene contents (relative area units expressed as peak area $\times 100 /$ internal standard peak area) in subcutaneous fat from Iberian pigs from the four categories of feeding systems studied (Bellota, Recebo, Campo and Cebo)

\begin{tabular}{lcccc}
\hline & Bellota & Recebo & Campo & Cebo \\
\hline $\mathrm{N}$ & 244 & 152 & 194 & 135 \\
Neophytadiene & $6.8 \pm 3.1 \mathrm{a}$ & $7.6 \pm 6.4 \mathrm{a}$ & $3.8 \pm 2.4 \mathrm{~b}$ & $0.3 \pm 0.2 \mathrm{c}$ \\
\hline
\end{tabular}

Means with different letters differ significantly $(p<0.001)$ according to the Mann-Whitney post hoc test.

al. (2001b) reported that the neophytadiene content in intramuscular lipids from $B$. femoris $m$. from pigs raised extensively for a long period of time is higher than in pigs raised for a short period with acorn and pasture, presumably because more pasture was consumed by the first category compared to second one. Therefore, the great variability observed in this study between batches from a same feeding category could be directly related with the environmental variability of the "dehesa" ecosystem. Several authors have evidenced the variations between montanera seasons in different years of study in the same geographical area and between distinct geographical areas, which demonstrates that the extensive rearing system is a dynamic and variable element (Gea-Izquierdo et al., 2006; Tejerina et al., 2010). These dynamic changes could be the explanation for the variability in the tissue composition of Iberian pigs and therefore on the quality of meat products from Iberian pigs reared according to this unique free-range system.

Table 2 shows the comparison of neophytadiene content among the four categories of feeding systems studied (Kruskal-Wallis test: $\mathrm{H} \quad(3$, $\mathrm{N}=730)=362.5 ; \mathrm{p}=0.000)$. No significant differences were observed between the Bellota and Recebo
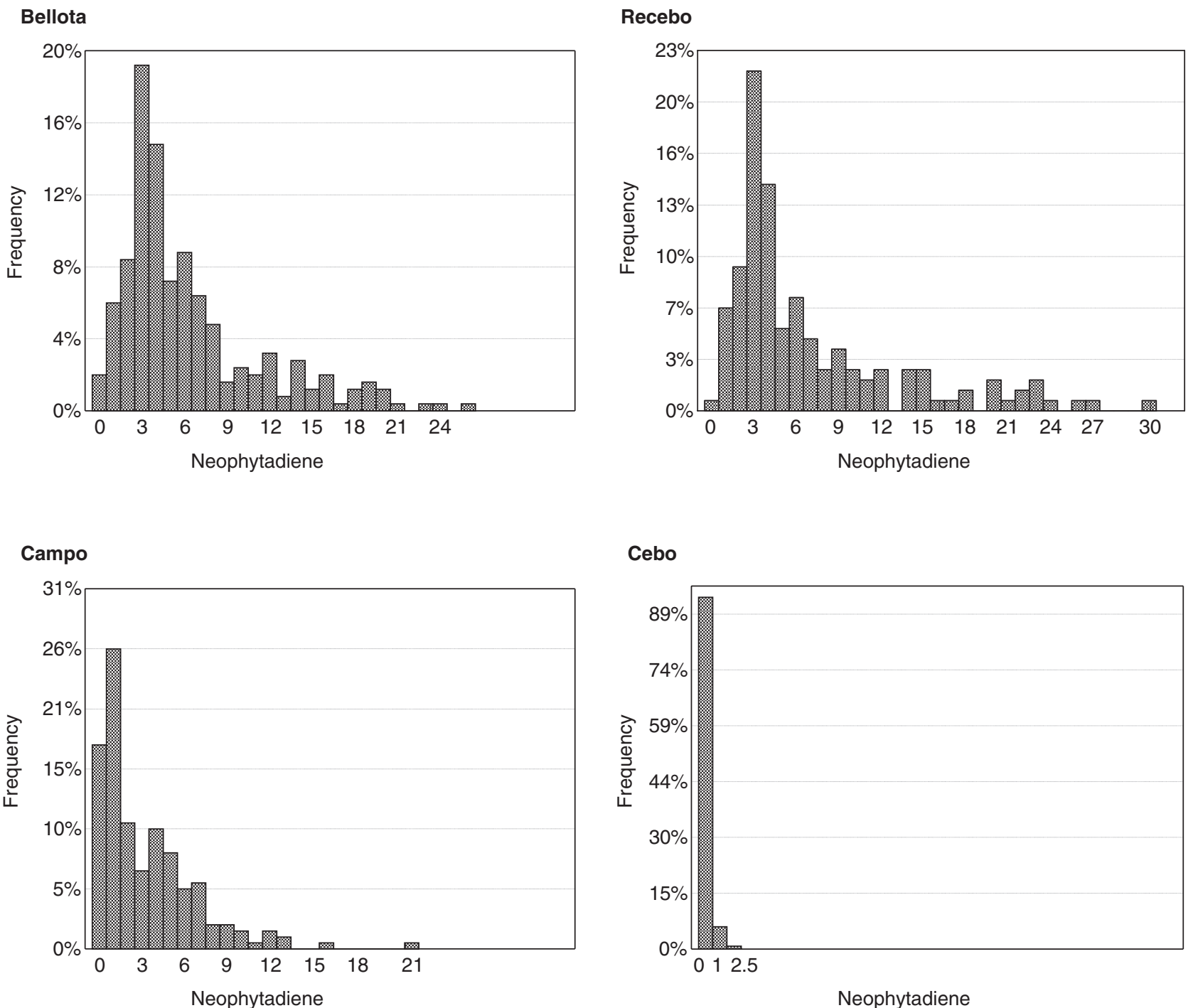

Cebo

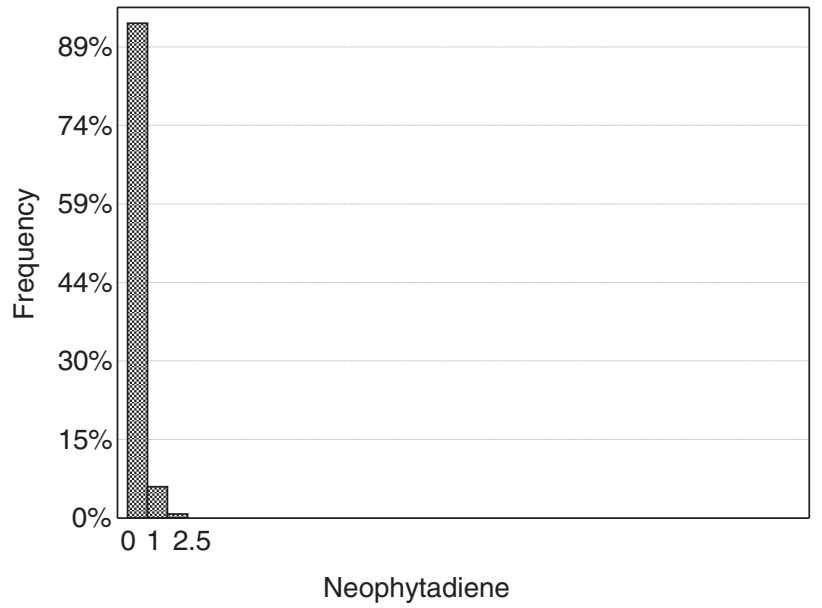

Figure 2

Histograms of relative frequencies of neophytadiene contents (relative area units expressed as peak area $\times 100 /$ internal standard peak area) in subcutaneous fat from Iberian pigs from the four categories of feeding systems studied (Bellota, Recebo, Campo and Cebo). 
batches. However, animals raised in these two range systems presented significantly higher $(p<0.001)$ contents of this branched hydrocarbon than Campo and Cebo Iberian pigs. Moreover, Cebo batches exhibited a significantly lower neophytadiene content, compared to the other three categories. These results are in agreement with previous works by Tejeda et al. (2001b) and Petrón et al. (2006) when comparing Iberian pigs raised according to Cebo and Montanera systems, in intramuscular lipids from fresh and dry-cured products, respectively.

Figure 2 represents the distribution of the samples in a relative frequency histogram for neophytadiene content for the different categories of feeding system studied. The results showed that when neophytadiene is not present in subcutaneous fat samples, they can only belong to Iberian pigs produced in intensive conditions without the consumption of pasture (Cebo category). When neophytadiene content is present in small amounts (between 0.0 and 1.3 relative area units), only $2 \%$ and $1 \%$ of the animals are classified as Bellota and Recebo categories, respectively; $33 \%$ of samples are classified as Campo; and finally, $96 \%$ of samples are classified as Cebo.

\section{CONCLUSIONS}

The presence of branched hydrocarbons, mainly neophytadiene, in the subcutaneous fat from Iberian pigs is related to their rearing system during the fattening period prior to slaughter. However, the levels of neophytadiene are variable among batches of the same category of feeding, as a consequence of the great variability of the "dehesa" system in different geographical areas and different years. Therefore, it is not possible to differentiate between Iberian pigs from Bellota and Recebo categories. The correct classification of pigs according to feeding systems is better in Campo and Cebo categories. Only Iberian pigs produced in intensive conditions throughout the production period were correctly assigned in all cases to the Cebo category.

\section{ACKNOWLEDGEMENT}

This study was supported by project RTA200800026-C07-07.

\section{REFERENCES}

Bandurski EL, Nagi, B. 1975. Nature of alkanes in beef heart lipids. Lipids 10, 67-69.

Bastic LJ, Bastic M, Remberg G, Skala D, Jovanovic J. 1989. Hydrocarbon content of neutral lipid fractions of different hog and cattle tissues. In Proc. $35^{\text {th }}$ ICOMST Copenhagen, 587-590.

Berdagué JL, García C. 1990. Les composants volatils du jambon sec. Viandes Produits Carnés 11, 319-320.
Bernardini MP, Boniforti L, Citti G, Mosini V. 1982. Distribution of hydrocarbons and fatty acids in meats imported into Italy. Food Chem. 8, 51-60.

Boletín Oficial del Estado. 2007. Real Decreto 1469/2007. B.O.E. no. 264 de 3 de noviembre de 2007, 4508745104. http://www.boe.es/boe/dias/2007/11/03/pdfs/ A45087-45104.pdf.

De Pedro E, Casillas M, Miranda CM. 1997. Microwave oven application in the extraction of fat from the subcutaneous tissue of Iberian pig ham. Meat Sci. 45, 45-51.

Fernández MF. 2007. Optimization of the technique for analysis of natural branched hydrocarbons in subcutaneous fat of Iberian pig. Tesina de Licenciatura, University of Extremadura, Badajoz, Spain.

Gamero-Pasadas A, Viera I, Rios JJ, Graciani E, Vicario IM, León-Camacho M. 2006. Characterization and quantification of the hydrocarbons fraction of the subcutaneous fresh fat of Iberian pig by off-line combination of high performance liquid chromatography and gas chromatography. J. Chromatogr. A 1123, 82-91.

García C, Berdagué JJ, Antequera T, López-Bote C, Córdoba JJ, Ventanas J. 1991. Volatile compounds of dry cured Iberian ham. Food Chem. 41, 23-32.

García-Casco JM, Muñoz M, González E. 2013. Predictive ability of the feeding system by means of several analytical methods in Iberian pigs. Grasas Aceites 64, 191-200.

Gea-Izquierdo G, Cañellas I, Montero M. 2006. Acorn production in Spanish holm oak woodlands. Invest. Agrar. Sist. Recur. For. 15, 339-354.

Lintas C, Balduzzi AM, Bernardini MP, Di Muccio A. 1979. Distribution of hydrocarbons in bovine tissues. Lipids 14, 298-303.

Mayes RW, Lamb CS. 1984. The possible use of $\mathrm{n}$-alkanes in herbage as indigestible faecal markers. Proc. Nut. Soc. 43, 39A.

Mayes RW, Lamb CS, Colgrove PM. 1988. Digestion and metabolism of dosed even-chain and herbage oddchain n-alkanes in sheep. Proc. $12^{\text {th }}$ General Meeting European Grasslands Fed. Dublin, Ireland, 159-163.

Narváez-Rivas M, Ríos JJ, Arteaga JF, Quilez JF, Barrero AF, León-Camacho M. 2008. Determination of ent-kaurene in subcutaneous fat of Iberian pigs by gas chromatography multi-stage mass spectrometry with the aim to differentiate between intensive and extensive fattening systems. Anal. Chim. Acta. 624, 107-112.

Narváez-Rivas M, Vicario IM, Alcalde MJ, León-Camacho M. 2010. Volatile hydrocarbon profile of Iberian drycured hams. A possible tool for authentication of hams according to the fattening diet. Talanta $\mathbf{8 1}$, 1224-1228.

Narváez-Rivas M, Pablos F, Jurado JM, León-Camacho M. 2011. Authentication of fattening diet of Iberian pigs according to their volatile compounds profile from raw subcutaneous fat. Anal. Bioanal. Chem. 399, 2115-2122.

Petrón MJ, Antequera T, Muriel E, Tejeda JF, Ventanas J. 2004. Linear hydrocarbons content of intramuscular lipids of dry-cured Iberian ham. Meat Sci. 66, 295-300.

Petrón MJ, Tejeda JF, Muriel E, Ventanas J, Antequera T. 2005. Study of the branched hydrocarbon fraction of intramuscular lipids from Iberian dry-cured ham. Meat Sci. 69, 129-134.

Petrón MJ, Muriel E, Tejeda JF, Ventanas J, Antequera T. 2006. Effect of duration of the Montanera diet on the hydrocarbon fraction of intramuscular lipids 
from Iberian dry-cured ham; characterization by gas chromatography. J. Sci. Food Agric. 86, 1040-1045.

Post-Beittenmiller D. 1996. Biochemistry and molecular bioligy of wax production in plants. Ann. Rev. Plant Physiol. Plant Mol. Biol. 47, 405-430.

Rembold $\mathrm{H}$, Wallner $\mathrm{P}$, Nite $\mathrm{S}$, Kollmannsberger $\mathrm{H}$, Drawert F. 1989. Volatile components of chickpea (Cicer arietinun L.) seed. J. Agric. Food Chem. 37, 659-662.

Ruiz J, García, C, Díaz, MC, Cava R, Tejeda JF, Ventanas J. 1999. Dry cured Iberian ham non-volatile components as affected by the length of the curing process. Food Res. Int. 32, 643-651.

Stryer L. 1990. Biosíntesis de lípidos de membrana y de hormonas esteroideas. In SA Reverte (Ed.) Bioquímica Vol. 2, Barcelona, Spain.

Tejeda JF, Antequera T, Ruiz J, Cava R, Ventanas J, García C. 1999. Unsaponifiable fraction content and n-alkane profiles of subcutaneous fat from Iberian hams. Food Sci. Tech. Int. 5, 41-45.

Tejeda JF, García C, Petrón MJ, Andrés AI, Antequera T. 2001a. n-Alkane content of intramuscular lipids of
Iberian fresh ham from different feeding systems and crossbreeding. Meat Sci. 57, 371-377.

Tejeda JF, Antequera T, Martín L, Ventanas J, García C. $2001 b$. Study of the branched hydrocarbon fraction of intramuscular lipids from Iberian fresh ham. Meat Sci. 58, 175-179.

Tejerina D, García-Torres S, Cabeza de Vaca M, Cava R, Vázquez FM. 2010. Interannual variability and evolution during the montanera period of Holm oak (Quercus rotundifolia Lam.) acorns. Spanish J. Agric. Res. 8, 634-641.

Tulliez JE, Bories GF. 1975. Métabolisme des hydrocarbures paraffiniques et naphténiques chez les animaux supérieurs. II. Accumulation et mobilisation chez le rat. Ann. Nut. Alim. 29, 213-221.

Tulliez JE, Bories GF. 1978. Metabolism of a n-paraffin, heptadecane, in rats. Lipids 13, 110-115.

Viera-Alcaide I, Narváez-Rivas M, Vicario IM, GracianiConstante E, León-Camacho M. 2009. Different fattening systems of Iberian pig according to 1-alkene hydrocarbon content in the subcutaneous fat. Grasas Aceites 60, 68-76. 